\title{
PELAKSANAAN PENDIDIKAN KARAKTER MELALUI KEGIATAN KESISWAAN DI MTS MISBAHUL HASAN ANDUNGSARI TIRIS PROBOLINGGO
}

\author{
Mohamad Ahyar Ma'arif \\ Email: ahyarqotrun19@gmail.com \\ Universitas Islam Zainul Hasan Genggong
}

\begin{abstract}
The Indonesian nation is facing a multidimensional crisis. From the results of studies of various disciplines and approaches, there seems to be a common view that all kinds of crises originate from moral or moral crises. This crisis is directly or indirectly, related to school or education issues. Research focus: (1) How to plan character education through student activities at Misbahul Hasan Andungsari Tiris Probolinggo MTs, (2) How to implement character education through student activities at Misbahul Hasan Andungsari Tiris Probolinggo MTs, and (3) How to evaluate character education through student activities at Misbahul Hasan Andungsari MTs Tiris Probolinggo. This research uses a qualitative approach with data collection methods of observation, interviews, and documentation. The data obtained were analyzed using descriptive analysis with steps of data reduction, data presentation and verification. The validity of the data uses triangulation of methods and sources. The results of the study show: (1) Planning for the implementation of character education through student activities in the Madrasah Tsanawiyah Misbahul Hasan Andungsari Tiris Probolinggo is relatively in accordance with planning in management. At least three elements of planning have been fulfilled namely: Choosing a set of activities, Deciding what to do next, when, how and by whom. When the implementation has been determined, the people directly involved are also clear, so the planning is only to run. (2) The implementation of character education through student activities in the Madrasah Tsanawiyah Misbahul Hasan Andungsari Tiris Probolinggo has been carried out according to applicable regulations, the madrasa head who has a model leadership in a hierarchy of needs has been able to move all components of the madrasa to consciously and responsibly jointly carry out their duties for the overall success of education., 3) Evaluation of character education through student activities in Tsanawiyah Madrasah Misbahul Hasan Andungsari Tiris Probolinggo has been relatively well underway. Evaluation developed by Madrasah Tsanawiyah Misbahul Hasan Andungsari Tiris.
\end{abstract}

Keywords: Implementation of Character Education, Student Activities. 


\section{Pendahuluan}

Dalam UU No 20 Tahun 2003 Tentang Sistem Pendidikan Nasional pada Pasal 3, disebutkan bahwa pendidikan nasional berfungsi mengembangkan kemampuan dan membentuk karakter serta peradaban bangsa yang bermartabat dalam rangka mencerdaskan kehidupan bangsa. Pendidikan nasional bertujuan untuk berkembangnya potensi peserta didik agar menjadi manusia yang beriman dan bertakwa kepada Tuhan Yang Maha Esa, berakhlak mulia, sehat, berilmu, cakap, kreatif, mandiri, dan menjadi warga negara yang demokratis serta bertanggung jawab. ${ }^{1}$

Peraturan Pemerintah Nomor 17 Tahun 2010 tentang Pengelolaan Penyelenggaraan Pendidikan pada Pasal 17 Ayat (3) menyebutkan bahwa pendidikan dasar, bertujuan membangun landasan bagi berkembangnya potensi peserta didik agar menjadi manusia yang (a) beriman dan bertakwa kepada Tuhan Yang Maha Esa; (b) berakhlak mulia, dan berkepribadian luhur; (b) berilmu, cakap, kritis, kreatif, dan inovatif; (c) sehat, mandiri, dan percaya diri; (d) toleran, peka sosial, demokratis, dan bertanggungjawab. Berdasarkan hal tersebut, jelas bahwa tujuan pendidikan di setiap jenjang, sangat berkaitan dengan pembentukan karakter peserta didik. $^{2}$

Begitu penting kajian pendidikan karakter atau akhlak ini dapat dirasakan di masa-masa sekarang ini, di mana masyarakat dihadapkan pada masalah moral dan akhlak yang cukup serius.praktek hidup yang menyimpang baik dari norma agama maupun norma sosial yang ada, menjadi pemandangan yang biasa. Bila kita melihat dengan jujur kehidupan berbangsa, bernegara, dan bermasyarakat dewasa ini, kita segera melihat bahwa kita sedang menghadapi krisis nasional yang bersifat multidimensional. Tidak berlebihan bila kita katakan, dewasa ini kita menghadapi krisis sosial, krisis akhlak, krisis politik, krisis disiplin nasional, krisis moneter/keuangan, dan bahkan krisis kemanusiaan. Ketimpangan sosial antara kelompok kaya dan kelompok miskin menganga sangat lebar, akhlak atau moral sebagian pemimpin dan masyarakat cenderung morat-marit yang pada gilirannya menimbulkan kepercayaan masyarakat pada pemerintah semakin tipis, uang rupiah yang semakin remuk, dan PHK serta pengangguran yang semakin lepas kendali, dan makin tumpulnya rasa kemanusiaan yang menghinggapi sebagian para penyelenggara Negara dan juga sebagian anggota masyarakat. ${ }^{3}$

Pendidikan karakter yang dimulai dari keteladanan, dalam Al Qur'an pun sudah dijelaskan sebagaimana tertera dalam QS. Al Baqarah : 44:

\footnotetext{
${ }^{1}$ Undang-Undang Republik Indonesia No.20 Tahun 2003 tentang Sistem Pendidikan Nasional.

${ }^{2}$ Peraturan Pemerintah Nomor 17 Tahun 2010 tentang Pengelolaan Penyelenggaraan Pendidikan

${ }^{3}$ Ahmad Syafi'i Maarif dkk, Indonesia di Simpang Jalan,( Bandung : Mizan, 1998),17.
} 


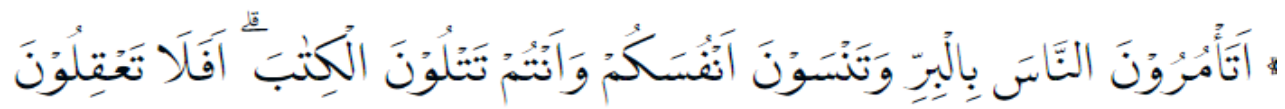

Artinya: "Mengapa kamu menyuruh orang lain (mengerjakan) kebajikan sedang kamu melupakan diri (kewajiban)mu sendiri, padahal kamu membaca Al Kitab (Taurat)? Maka tidaklah kamu berfikir",4

Namun untuk mewujudkan generasi yang berkarakter atau generasi Qur'ani, sebagaimana yang dicontohkan oleh Rasulullah SAW bukan sesuatu hal yang mudah.Ia harus diusahakan secara teratur dan berkelanjutan baik melalui pendidikan informal seperti dalam keluarga, pendidikan formal atau melalui pendidikan non formal (masyarakat). Generasi Qur'ani tidak lahir dengan sendirinya, tetapi ia dimulai dari pembiasaan dan pendidikan dalam keluarga., misalnya menanamkan pendidikan agama yang sesuai dengan tingkat perkembangannya, sebagaimana hadits Nabi Muhammad SAW yang diriwayatkan oleh HR. Abu Daud: "Perintahlah anak-anakmu mengerjakan sholat, lantaran ia sudah berumur tujuh tahun, pukullah mereka setelah mereka berumur sepuluh tahun dan pisahkan tempat tidurmu dan tempat tidur mereka." ${ }^{5}$

Berdasarkan hal-hal tersebut di atas maka saya tertarik ingin meneliti kemudian mendiskripsikan bagaimana pelaksanaan pendidikan karakter melalui kegiatan kesiswaan di MTs. Misbahul Hasan Andungsari Tiris Probolinggo.Karena banyak hal yang unik dan menarik yang berkaitan dengan kegiatan kesiswaan yang membangun peserta didik kearah pendidikan karakter, Penelitian ini dilakukan di MTs. Misbahul Hasan Andungsari Tiris Probolinggo.Peneliti tertarik dengan lembaga ini meskipun swasta dan diapit oleh dua lembaga milik pemerintah yang cukup maju dan favorit di wilayah Tiris Probolinggo namun tetap eksis dalam berjuang membangun lembaganya dengan semangat dan kesederhanaan.Diantaranya adalah upaya pendidikan kedisiplinan peserta didik dengan ada tim khusus pembina tata tertib yang salah satu tugasnya adalah membangun kesadaran peserta didik agar sadar hukum/tata tertib sekolah sehingga mampu meminimalisir budaya terlambat atau pelanggaran tata tertib sekolah, tradisi salaman ucap salam bila ketemu dengan warga sekolah, pembacaan surat-surat pendek sebelum pembelajaran dimulai, dihari tertentu diselingi pembacaan yasin dan asmaul husna, sholat dhuhur berjamaah, setiap hari jumat satu jam pertama diadakan bersih lingkungan dan senam kesegaran jasmani, Putra, 1989)

${ }^{4}$ Departemen agama Rebuplik Indonesia,,Al quran dan Terjemah, (Semarang: Toha

5 Said Agil Husin Al Munawar, Al Qur'an:Membangun Tradisi Kesalihan Hakiki (Jakarta: Ciputat Press, 2002),353. 
setiap dua minggu sekali tepatnya pada hari senin menjadi agenda rutin untuk melaksanakan upacara bendera, selain itu masih banyak kegiatan ekstra kurikuler yang mencerminkan pendidikan karakter misalkan pramuka, olahraga, remus, PHBI dan lain-lain.Itulah gambaran kondisi kegiatan kesiswaan di MTs. Misbahul Hasan Andungsari Tiris Probolinggoyang mendasari penulis untuk melakukan penelitian tentang Pelaksanaan Pendidikan Karakter Melalui Kegiatan Kesiswaan di MTs . Misbahul Hasan Andungsari Tiris Probolinggo.

\section{Pembahasan}

\section{A. Pendidikan karakter}

Pendidikan karakter adalah suatu sistem penanaman nilai-nilai karakter kepada warga sekolah yang meliputi komponen pengetahuan, kesadaran atau kemauan, dan tindakan untuk melaksanakan nilai-nilai tersebut. ${ }^{6}$ Pendidikan karakter sebenarnya mempunyai makna dan maksud yang sama dengan pendidikan moral dan akhlak. Oleh karena itu, hakikat dari pendidikan karakter dalam konteks pendidikan di Indonesia adalah pedidikan nilai, yakni pendidikan nilai-nilai luhur yang bersumber dari budaya bangsa Indonesia sendiri, dalam rangka membina kepribadian generasi muda. ${ }^{7}$

Pada dasarnya secara garis besar manusia memiliki dua karakter yang berlawanan hal ini diisyaratkan dalam Al-Quran, surat As Syam ayat 8 :

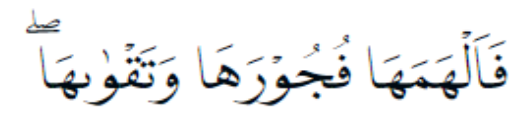

Artinya:" Maka Allah mengilhamkan kepada jiwa itu (jalan) kefasikan dan ketakwaannya. Sesungguhnya beruntunglah orang yang mensucikan jiwa itu, Dan Sesungguhnya merugilah orang yang mengotorinya." 8

Doni A koesoema mengajukan lima metode pendidikan karakter (dalam penerapan di lembaga sekolah) yaitu: ${ }^{9}$ 1) Mengajarkan ;Pemahaman konseptual tetap dibutuhkan sebagai bekal. Konsep-konsep nilai yang kemudian menjadi rujukan bagi perwujudan karakter tertentu: mengajarkan karakter berarti memberikan pemahaman pada peserta didik tentang struktur nilai tertentu, keutamaan (bila dilaksanakan), dan maslahatnya (bila tidak dilaksanakan). Mengajarkan nilai memiliki dua faedah, pertama memberikan pengetahuan 2010), 8 .

${ }^{6}$ Kemendikbud, Buku Panduan Pendidikan Karakter di Sekolah Menengah Pertama,( 2010), 8.

${ }^{7}$ Kemendikbud, Buku Panduan Pendidikan Karakter di Sekolah Menengah Pertama,(

${ }^{8}$ Departemen, Al-Qur'an..595.

${ }^{9}$ Doni A. Koesoema, Pendidkan Karakter, (Jakarta: Grasindo, 2007), 212-217. 
konseptual baru, kedua, menjadi pembanding atas pengetahuan yang dimiliki oleh peserta didik. Karena itu maka "mengajarkan" tidaklah monolog melainkan melibatkan peran peserta didik. 2) Keteladanan; Manusia lebih banyak belajar dari apa yang mereka lihat. Keteladanan menempati posisi yang sangat penting. Guru adalah yang digugu dan di tiru, peserta didik akan meniru apa yang dilakukan gurunya daripada yang dikatakan guru. Bahkan, sebuah pepatah kuno member peringatan pada guru bahwa peserta didik akan meniru karakter negative secara lebih ekstrem daripada gurunya, "guru kencing berdiri murid kencing berlari". Keteladanan tidak hanya berrsumber dari guru, melainkan juga dari seluruh manusia yang ada dilembaga pendidikan tersebut, juga bersumber dari orang tua, karib kerabat, dan sepupu yang sering berhubungan dengan peserta didik.Pada titik ini, pendidikan karakter membutuhkan lingkungan pendidikan yang utuh, saling mengajarkan karakter. 3) Menentukan prioritas; Penentuan prioritas yang jelas harus ditentukan agar proses evaluasi atas berhasil tidaknya pendidikan karakter dapat menjadi jelas. Tanpa prioritas, pendidikan karakter tidak dapat terfokus karena tidak dapat di nilai berhasil atau tidak berhasil. Pendidikan karakter menghimpun kumpulan nilai yang dianggap penting bagi pelaksanan dan evaluasi visi lembaga. Oleh karena itu lembaga pendidikan memiliki beberapa kewajiban, pertama, menentukan standar yang akan ditawarkan pada peserta didik. Kedua, semua pribadi yang terlibat dalam lembaga pendidikan harus memahami secara jernih apa nilai yang ingin ditekankan dalam lembaga pendidikan karakter, ketiga, jika lembaga ingin menetapkan perilaku standar yang menjadi cirri khas lembaga maka karakter standar itu harus dipahami oleh anak didik, orang tua, dan masyarakat. 4) Praksis prioritas; Unsur lain yang sangat penting setelah prioritas karakter adalah bukti dilaksanakannya prioritas karakter tersebut. Lembaga pendidikan harus mampu membuat verifikasi sejauh mana prioritas yang telah ditentukan telah dapat dilaksanakan dalam lingkup pendidikan.Melalui berbagai unsur yang ada dalam lembaga pendidikan itu. 5) Refleksi; Refleksi berarti dipantulkan kedalam diri apa yang telah dialami masih tetap terpisah dengan kesadaran diri sejauh ia belum dikaitkan. Dipantulkan dengan isi kesadaran seseorang. Refleksi dapat juga di sebut sebagai proses bercermin. Mematut-matutkan diri pada peristiwa /konsep yang telah teralami.Apakah saya seperti itu?Apakah ada karakter baik seperti itu pada diri saya?

Dalam rangka memperkuat pelaksanaan pendidikan karakter, pemerintah telah mengidentifikasi 18 nilai karakter yang berdasarkan agama, budaya, dan falsah bangsa, yaitu : 1) religius, 2) jujur, 3) toleransi, 4) disiplin, 5) kerja keras, 6) kreatif, 7) mandiri, 8) demokratis, 9) rasa ingin tahu, 10) semangat kebangsaan, 11) cinta tanah air, 12) menghargai prestasi, 13) bersahabat/komunikatif, 14) cinta 
damai, 15) gemar membaca, 16) peduli lingkungan, 17) peduli sosial, dan 18) tangggng jawab. ${ }^{10}$

\section{B. Kegiatan Kesiswaan}

Implementasi dalam kegiatan pembinaan kesiswaan adalah bentuk kegiatan yang dilakukan oleh lemabaga pendidikan di luar jam pelajaran tatap muka dengan tujuan untuk memperluas pengetahuan, keterampilan, dan mampu menginternalisasi nilai-nilai agama serta norma sosial baik lokal, nasional untuk membentuk manusia atau peserta didik yang seutuhnya.

Adapun tujuan kegiatan pembinaan kesiswaan adalah sesuai dengan yang tercantum dalam Permendiknas No. 39 Tahun 2008, yaitu: ${ }^{11}$ Mengembangkan potensi siswa secara optimal dan terpadu yang meliputi bakat, minat dan kretivitas; Memantapkan kepribadian siswa untuk mewujudkan ketahanan sekolah sebagai lingkungan pendidikan sehingga terhindar dari usaha dan pengaruh negatif dan bertentangan dengan tujuan pendidikan; Mengaktualisasikan potensi siswa dalam pencapaian prestasi unggulan sesuai bakat dan minat; Menyiapkan siswa agar menjadi warga masyarakat yang berakhlak mulia, demokratis, menghormati hak-hak asasi manusia dalam rangka mewujudkan masyarakat madani.

Permendiknas Nomor 39 Tahun 2008 tentang Pembinaan Kesiswaan menyebutkan sepuluh kelompok nilai karakter yang dikembangkan pada peserta didik melalui kegiatan pembinaan kesiswaan, yaitu: ${ }^{12}$ Keimanan dan ketaqwaan terhadap Tuhan Yang Maha Esa;Budi pekerti luhur atau akhlak mulia; Kepribadian unggul, wawasan kebangsaan, dan bela negara; Prestasi akademik, seni, dan/atau olahraga sesuai bakat dan minat; Demokrasi, hak asasi manusia, pendidikan politik, lingkungan hidup, kepekaan dan toleransi sosial dalam konteks masyarakat plural; Kreativitas, keterampilan, dan kewirausahaan; Kualitas jasmani, kesehatan, dan gizi berbasis sumber gizi yang terdiversifikasi ; Sastra dan budaya; Teknologi informasi dan komunikasi; Komunikasi dalam bahasa Inggris;

Kesepuluh kelompok nilai tersebut dijabarkan menjadi berbagai kegiatan yang secara rinci disebutkan dalam lampiran Permendiknas Nomor 39 Tahun 2008. Apabila ditelaah lebih jauh, rincian dari Permendiknas tersebut di atas tidak berbeda dengan dua puluh nilai-nilai utama yang dikelompokkan menjadi nilainilai yang berhubungan dengan Ketuhanan, diri sendiri, sesama manusia, lingkungan dan kebangsaan yang merupakan fokus dari pendidikan karakter .

10 Amirulloh Syarbini, Buku Pintar Pendidikan Karakter; Panduan Lengkap Mendidik Karakter Anak di Sekolah, Madrasah, dan Rumah, (Jakarta: as@--Prima pusaka, 2012), 25.

${ }^{11}$ Permendiknas no.39 tahun 2008, pasal 1.

${ }^{12}$ Permendiknas no 39 tahun 2008, pasal 3 ayat 2 hal 4-5. 
Dalam memantapkan kepribadian peserta didik guna mewujudkan nilainilai karakter sesuai dengan tujuan pendidikan nasional, maka pendidikan karakter melalui kegiatan pembinaan kesiswaan diupayakan antara lain dalam bentuk kegiatan: (1) Pembinaan keimanan dan ketakwaan terhadap Tuhan Yang Maha Esa; (2) Masa Orientasi Siswa (MOS); (3) Organisasi Siswa Intra Sekolah (OSIS); (4) Penegakan Tatakrama dan Tata Tertib Kehidupan Akademik dan Sosial Sekolah; (5) Kepramukaan; (6) Upacara Bendera; (7) Usaha Kesehatan Sekolah (UKS); (8) Palang Merah Remaja (PMR); (9) Pendidikan Pencegahan Penyalahgunaan Narkoba; (10) Pembinaan Bakat dan Minat. ${ }^{13}$

\section{Perencanaan Pendidikan Karakter melalui kegiatan Kesiswaan.}

Perancanaan pada hakikatnya adalah aktivitas pengambilan keputusan tentang sasaran apa yang akan dicapainya, tindakan apa yang akan diambil dalam rangka mencapai tujuan atau sasaran tersebut. Pembuatan perencanaan kegitan pelaksanaan pendidikan karakter menuntut setiap warga sekolah untuk tidak mengabaikan visi,misi dan tujuan lembaga/sekolah yang telah dibuat secara bersama.Penyusunan rencana program madrasah harus dapat mengakomodir berbagai program yang berkaitan dengan pengembangan nilai-nilai, seperti disiplin, hormat, cinta tanah air, cinta ilmu dan lain sebagainya.Selain itu, penyusunan rencana program madrasah harus melibatkan berbagai pihak yang berkepentingan (stake holder). ${ }^{14}$ Tanggung jawab perencanaan peserta didik, sebagaimana manajemen peserta didik, secara formal berada di tangan kepala sekolah, sedangkan secara material tanggung jawab berada di tangan wakil kepala sekolah urusan kesiswaan. Meskipun demikian bukan berarti wakil kepala sekolah merencanakan sendiri urusan kesiswaan, wakil kepala sekolah dapat meminta bantuan kepada guru atau tenaga kependidikan yang lain di sekolah itu. ${ }^{15}$ Perencanaan program dan kegiatan madrasah dilakukan melalui pengembangan dan penyusunan rencana kerja madrasah (RKM) untuk jangka menengah atau panjang dan rencana kegiatan dan anggaran madrasah (RKAM) untuk jangka pendek atau tahunan. ${ }^{16}$ Dalam upaya pendidikan karakter, madrasah bersama dengan pemangku kepentingan menyusun RKM dan RKAM ini melalui berbagai proses yang dapat menumbuhkembangkan nilai-nilai karakter. Melalui proses perencanaan yang baik diharapkan akan memunculkan berbagai nilai

${ }^{13}$ Kemendikbud, Buku Panduan Pendidikan Karakter di Sekolah Menengah Pertama, Tahun 2010,hal. 95.

${ }^{14}$ Heri Gunawan,Pendidikan Karakter (Konsep dan Implementasi). (Bandung: Alfabeta, 2012), 249

${ }^{15}$ Ali Imron, Manajemen Peserta Didik Berbasis Sekolah, (Jakarta : PT. Bumi Aksara, 2011), 20.

${ }^{16}$ Heri Gunawan,Pendidikan Karakter (Konsep dan Implementasi). (Bandung: Alfabeta, 2012), 249. 
karakter yang baik pula. ${ }^{17}$ Perencanaan terjadi di semua tipe kegiatan. Perencanaan adalah proses dasar dimana manajemen memutuskan tujuan dan caramencapainya. Secara rinci perencanaan adalah pemilihan sekumpulan kegiatan dan pemutusan selanjutnya apa yang harus dilakukan, kapan, bagaimana dan oleh siapa. ${ }^{18}$ Dengan demikian perencanaan memiliki fungsi antara lain menentukan tujuan atau kerangka tindakan yang diperlukan untuk mencapai tujuan tertentu. Ini dilakukan dengan mengkaji kekuatan dan kelemahan organisasi, menentukan kesempatan dan ancamanya, menentukan strategi, kebijakan, taktik dan program, semua itu dilakukan berdasarkan pengambilan keputusan secarah ilmiah.

1. Pertimbangan dalam menentukan kegiatan kesiswaan yang mengembangkan nilai-nilai karakter.

Perencanaan kegiatan harus matang sebelum dijalankan, dengan mempertimbangkan prediksi futuristik disemua aspek yaitu apa yang harus dikerjakan, bagaimana kondisi internal dan eksternal. Selain itu perencanaan kegiatan ini harus fleksibel, dapat menangkap dan mengakomodir segala perubahan yang terjadi.Perencanaan yang dilakukan harus disesuaikan dengan keadaan situasi kondisi pada masa lampau, saat ini, serta prediksi masa datang. ${ }^{19}$ Kegiatan pembinaan kesiswaan merupakan bagian dari proses pendidikan karakter di sekolah dan peningkatan mutu pendidikan. Kegiatan pembinaan kesiswaan dirancang dalam rangka meningkatkan mutu pendidikan di sekolah yang memperkuat penguasaan kompetensi dan memperkaya pengalaman belajar peserta didik dengan tetap membentuk nilai-nilai yang sesuai dengan karakter bangsa.Dengan demikian, pembinaan kesiswaan di SMP perlu didukung oleh sumber daya yang relevan dengan situasi dan kondisi sekolah serta perkembangan peserta didik. Artinya, pembinaan kesiswaan dalam rangka membentuk karakter akan sangat bergantung kepada faktor-faktor seperti: (a) pemahaman pendidik terhadap kondisi obyektif peserta didik; (b) tingkat penguasaan kompetensi pendidik; (c) tujuan yang akan dicapai; (d) proses pelaksanaan yang direncanakan; (e) materi kegiatan yang dikembangkan; dan (f) dukungan kelembagaan sekolah, baik berupa tenaga, dana, maupun sarana/prasarana pembinaan karakter. ${ }^{20}$

2. Peran warga sekolah dalam pembinaan karakter melalui kegiatan kesiswaan.

\footnotetext{
${ }^{17}$ Heri Gunawan,Pendidikan Karakter (Konsep dan Implementasi). (Bandung: Alfabeta, 2012), 249.

${ }^{18}$ T. Hani Handoko, Manajemen,(Yogyakarta: BPFE-Yogyakarta, 2000),77.

${ }^{19}$ Didin Hafifuddin, Manajemen Syariah dalam Praktik, (Jakarta: Gema Insani Perss, 2008), 79.

${ }^{20}$ Muhaimin, Pengembangan Kurikulum Pendidikan Agama Islam di Sekolah, Madrasah, dan Perguruan Tinggi, (Jakarta: PT RajaGrafindo Persada, 2010), 61.
} 
Bahwa dalam pembinaan karakter peserta didik di satuan pendidikan tidak terlepas dari peran serta kepala madrasah, guru, tenaga pendidik dan orang tua. Dalam pembinaannya peserta didik membutuhkan nasihat yang baik yang dikenal dengan bil lisan dengan menyentuh hati dan pola pikiran peserta didik. Keteladanan yang disebut dengan bil hal sebagai bentuk bahwa kepala madrasah, guru, tenaga pendidik dan orang tua patut diteladani perilaku kesehariannya. Sebab mereka adalah figur bagi genarasi muda atau peserta didik, pendidikan selain transfer pengetahuan juga sebagai transfer budaya atau pembiasaan yang di contohkan oleh kepala madrasah/sekolah, guru, tenaga pendidik dan orang tua. Sedangkan bi al-kitabah dalam mengimplementasikan pendidikan karakter pada siswa atau peserta didik melalui materi pelajaran yang mencermin ajakan pada perilakau yang baik yang ditopang dengan metode pembelajaran.

Pengembangan nilai-nilai dalam pendidikan karakter melalui budaya sekolah mencakup semua kegiatan-kegiatan yang dilakukan kepala sekolah, guru, konselor, tenaga administrasi dan peserta didik.Interaksi yang terjadi meliputi antara peserta didik berinteraksi dengan sesamanya, kepala sekolah dengan guru, guru dengan guru, guru dengan siswa, konselor dengan siswa dan sesamanya, pegawai administrasi dengan dengan siswa, guru dan sesamanya. Interaksi tersebut terikat oleh berbagai aturan, norma, moral serta etika bersama yang berlaku di suatu sekolah. Kepemimpinan, keteladanan, keramahan, toleransi, kerja keras, disiplin, kepedulian sosial, kepedulian lingkungan, rasa kebangsaan, tanggung jawab dan rasa memiliki merupakan sebagian dari nilai-nilai yang dikembangkan dalam budaya sekolah.Proses pendidikan karakter melibatkan siswa secara aktif dalam semua kegiatan keseharian di sekolah. Dalam kaitan ini, kepala sekolah, guru, dan tenaga kependidikan lain diharapkan mampu menerapkan prinsip "tut wuri handayani" dalam setiap perilaku yang ditunjukkan peserta didik. Prinsip ini juga menyatakan bahwa proses pendidikan dilakukan dalam suasana belajar yang menyenangkan dan tidak indoktrinatif. ${ }^{21}$

3. Langkah-langkah sekolah dalam menyelenggarakan pendidikan karakter melalui kegiatan kesiswaan.

Ada beberapa hal yang perlu dilakukan dalam menyusun perencanaan, antara lain :Mengidentifikasi jenis-jenis kegiatan di madarasah yang dapat merealisasikan pendidikan karakter yang perlu dikuasai dan direalisasikan oleh siswa atau peserta didik dalam kehidupan

${ }^{21}$ Kemendikbud, Buku Panduan Pendidikan Karakter di Sekolah Menengah Pertama, Tahun 2010,hal. 95 
sehari-hari;Mengembangkan materi pembelajaran untuk setiap jenis kegiatan di madrasah;Mengembangkan rancangan pelaksanaan setiap pelaksanaan (tujuan, materi, fasilitas, jadwal, pengajar,/fasilitator, pendekatan pelaksanaan, evaluasi);Menyiapkan fasilitas pendukung pelaksanaan program pembentukan karakter di madrasah. ${ }^{22}$ Keberadaan suatu rencana sangat penting bagi suatu organisasi karena berfungsi untuk $:{ }^{23}$ Menjelaskan dan merinci tujuan yang ingin dicapai, Memberikan pegangan dan penetapan kegiatan-kegiatan yang harus dilakukan untuk mencapai tujuan organisasi dengan memperoleh sumber daya terbaik dan mengimplementasikan sesuai tugas pokok fungsi yang telah ditetapkan. Oleh karena itu, menjadi rujukan anggota organisasi dalam melaksanakan aktifitas yang konsisten prosedur dan tujuan, Memberikan batas kewenangan dan tangung jawab bagi seluruh pelaksana, Memonitor dan mengukur berbagai keberhasilan secara intensif sehingga dapat menemukan dan memperbaiki penyimpangan secara dini, Memungkinkan untuk terpeliharanya persesuaian antara kegiatan internal dengan situasi eksternal, Menghindari pemborosan.

Ada empat tahap dasar perencanaan yaitu : (1) menetapkan tujuan atau serangkaian tujuan. (2) merumuskan keadaan saat ini (3) mengidentifikasikan segala kemudahan dan hambatan (4) mengembangkan rencana atau serangkaian kegiatan untuk pencapaian tujuan. ${ }^{24}$

\section{Metode Penelitian}

Penelitian ini menggunakan pendekatan kualitatif dengan metode pengumpulan data observasi, Interview, dan dokumentasi. Pengecekan keabsahan data menggunaan triangulasi data. Data yang diperoleh akan dianalisis dengan menggunakan analisa deskriptif dengan langka-langkah reduksi data, penyajian dan verifikasi data / penarikan kesimpulan. Sedangkan keabsahan data menggunakan triangulasi metode dan sumber.

\section{Hasil Penelitian}

A. Perencanaan Pendidikan Karakter Melalui Kegiatan Kesiswaan Di Madrasah Tsanawiyah Misbahul Hasan Andungsari Tiris Probolinggo.

1. Proses penyusunan perencanaan pelaksanaan pendidikan karakter melalui kegiatan kesiswaan di MTs .Misbahul Hasan Andungsari Tiris Probolinggo

${ }^{22}$ Zainal Aqib, Sujak, Panduan dan Aplikasi Pendidikan Karakter ... 15-16.

23 Tim Dosen Administrasi Pendidikan UPI, Manajemen Pendidikan, ( Bandung : Alfabeta, 2008) 93-94.

${ }^{24}$ T. Hani Handoko, Manajemen, (Yogyakarta: BPFE-Yogyakarta, 2000), 78. 
Proses penyusunan perencanaan pendidikan karakter melalui kegiatan kesiswaan, MTs .Misbahul Hasan Andungsari Tiris Probolinggo dengan melakukan rapat koordinasi kepala madrasah dengan para PKM (pembantu kepala madrasah) untuk membahas lebih lanjut mengenai program-program sekolah, dan itu dilakukan sebelum tahun ajaran baru dimulai kemudian ditindak lanjuti oleh rapat tim kesiswaan, juga di bahas dalam rapat dinas atau rapat rutin bulanan, banyak hal yang dibahas dalam pertemuan itu di antaranya menentukan tujuan kegiatan, menentukan siapa pelaksana dan penanggung jawab kegiatan, kapan kegiatan itu dilakukan, dan berapa dana yang diperlukan.

Situasi dan kondisi karakter bangsa yang sedang memprihatinkan telah mendorong pemerintah untuk mengambil inisiatif untuk memprioritaskan pembangunan karakter bangsa.Pembangunan karakter bangsa dijadikan arus utama pembangunan nasional. Terwujudnya peserta didik yang berkarakter perlu dipersiapkan perencanaannya, hal ini sudah dilakukan MTs Misbahul Hasan Andungsari Tiris Probolinggo dengan upaya kepala sekolah mengumpulkan para staf jauh sebelum tahun ajaran baru di mulai untuk membahas tentang rencana-rencana kegiatan yang berkaitan dengan tujuan kegiatan, kapan kegiatan itu dilakukan dan siapa pelaksananya dan butuh dana berapa. Senada dengan pernyataan diatas, Didin mengemukakan, dalam melakukan perencanaan, ada beberapa aspek yang harus diperhatikan antara lain (1) hasil yang ingin dicapai, (2) orang yang akan melakukan, (3) waktu dan skala prioritas (4) dana (capital) ${ }^{25}$

Untuk menanggulangi masalah tersebut, baik sosial maupun fisikal serta untuk mengatasi perencanaan pendidikan karakter yang saat ini masih belum memadai bagi lembaga-lembaga pendidikan utamanya MTs . Misbahul Hasan Andungsari Tiris Probolinggo, maka yang harus dilakukan adalah perencanaan pendidikan karakter bisa berangkat dari pengalaman yang sudah terjadi sebelumnya, baik itu intern maupun ekstern lembaga, mengklasifikasikan rencana jangka pendek, jangka menengah dan jangka panjang, ini dimaksudkan untuk mempermudah evaluasi dan mengatasi secara dini jika terjadi permasalahan yang muncul.

2. Pertimbangan dalam menentukan kegiatan kesiswaan yang mengembangkan nilai-nilai karakter.

Lembaga Madrasah Tsanawiyah Misbahul Hasan Andungsari Tiris Probolinggo sudah berupaya melakukan tahapan-tahapan untuk menentukan kegiatan apa yang bisa mengembangkan pendidikan karakter melalui kegiatan kesiswaan. Tahapan-tahapan yang dilakukan oleh MTs 2008), 77.

25 Didin Hafifuddin, Manajemen Syariah dalam Praktik, (Jakarta: Gema Insani Perss, 
.Misbahul Hasan Andungsari Tiris Probolinggo adalah: Pertama, kepala madrasah melakukan rapat koordinasi dengan tim kesiswaan untuk menganalisis kegaiatan-kegiatan apa yang cocok dan sesuai dengan kondisi sekolah, termasuk peserta didik, sumberdaya manusia yang ada, sarana prasarana yang mendukung, kedua juga mempertimbangkan kondisi internal dan eksternal sekolah dengan melakukan pengamatan-pengamatan atau analisa-analisa termasuk peserta didik, sumberdaya manusia yang ada, sarana prasarana yang mendukung,dan dampak perkembangan teknologi informasi dan komunikasi. Ketiga dalam pertemuan tersebut menghasilkan keputusan kegiatan-kegiatan kesiswaan yang dipilih yaitu : kegiatan keagamaan, MOS, OSIS, pramuka, upacara bendera, penekakkan tatatertib sekolah, sepak bola, bola volley dan seni drumb band. Keempat,perencanaan kegiatan itu harus disesuaikan dengan kondisi saat ini, dan yang akan datang.

3. Peran warga sekolah/komite dalam pembinaan pendidikan karakter melalui kegiatan kesiswaan.

Dari temuan penelitian menegaskan bahwa Sebuah rencana yang matang akan bisa berjalan dengan baik, tentunya tidak terlepas dari peran semua pihak, di madrasah ini peran serta warga sekolah kepala madrasah, guru, karyawan dan pihak terkait untuk mensukseskan program pendidikan karakter melalui kegiatan kesiswaan sangat baik hal ini di buktikan dengan berjalannya seluruh kegiatan kesiswaan sesuai rencana dan jadwal yang telah ditetapkan.

Oleh karenanya sebelum memutuskan mengenai kegiatan apa yang akan di programkan. Kepala madrasah selalu mengajak urun rembug/musyawarah dengan para PKM sebelum rapat dinas awal Tahun Ajaran Baru di mulai, kemudian masing-masing PKM mulai PKM kurikulum, PKM humas, PKM sarana, dan PKM kesiswaan melakukan rapat koordinasi dengan masing-masing timnya untuk membahas lebih lanjut program-program sekolah sesuai dengan tugas dan tanggung jawabnya, baru setelah itu rapat dengan semua dewan guru, dan karyawan termasuk dalam hal ini pembina kegiatan kesiswaan dan pihak-pihak terkait. Namun dalam temuan penelitian, peneliti belum menemukan data yang menunjukkan bahwa MTs .Misbahul Hasan Andungsari Tiris Probolinggo melibatkan peran komite sekolah dalam proses penyusunan perencanaan pelaksanaan pendidikan karakter melalui kegiatan kesiswaan, hanya melibatkan komite sekolah pada tahap sosialisasi pendidikan karakter melalui rapat-rapat komite dan wali murid.

Dalam melibatkan peran warga sekolah untuk penyusunan perencanaan pelaksanaan pendidikan karakter, MTs .Darul Hikmah sudah 
melakukan sesuai dengan teori yang ada, namun belum melibatkan sepenuhnya warga sekolah dalam hal ini komite sekolah.Namun secara umum MTs. Misbahul Hasan Andungsari Tiris Probolinggo sudah sudah melakukan tahapan-tahapan yang harus dilakukan, misalnya sosialisasi pendidikan karakter dengan meminta dukungan kepada orang tua siswa dalam rapat-rapat wali murid ketika moment pengambilan raport.

Apabila kita perhatikan waktu yang digunakan anak selama dua puluh empat jam, sebagian besar mereka habiskan di lingkungan masyarakat maka dalam pembentukan karakter peserta didik pun tidak terlepas dari pengaruh masyarakat dan lingkungannya.Agar pengaruh yang diberikan oleh lingkungan itu positif bagi pembentukan karakter peserta didik diperlukan peran komite.Sehingga dalam pelaksanaan pendidikan karakter komite berperan sebagai pemberi pertimbangan dalam penentuan pelaksanaan kebijakan pendidikan karakter disekolah/madrasah.Yang kedua, berperan sebagai pendukung baik yang berwujud finansial, pemikiran, maupun tenaga dalam penyelenggaraan pendidikan karakter.Ketiga bisa berperan sebagai pengontrol dalam rangka transparansi dan akuntabilitas penyelenggaraan dan keluaran mutu pendidikan karakter. Keempat, berperan sebagai mediator antara pemerintah dengan masyarakat, sekolah, dalam implementasi pendidikan karakter.

\section{B. Pelaksanaan pendidikan Karakter melalui Kegiatan Kesiswaan di Madrasah Tsanawiyah Misbahul Hasan Andungsari Tiris Probolinggo}

Dunia yang semakin mengglobal sekarang ini, bergerak dan berubah semakin cepat dan kompetitif.Semua bidang mengalami pergeseran dan tantangan, termasuk sekolah sebagai lembaga pendidikan. Sekolah menghadapi tantangan serius untuk mampu mengikuti sekaligus berada di garda depan perubahan global tersebut. Upaya pendidikan dalam rangka pembangunan manusia Indonesia seutuhnya, memberikan makna perlunya pengembangan seluruh dimensi aspek kepribadian secara serasi, selaras, dan seimbang.Konsep manusia seutuhnya harus dipandang memiliki unsur jasad, akal, dan kalbu serta aspek kehidupannya sebagai makhluk individu, sosial, susila, dan agama.Kesemuanya harus berada dalam kesatuan integralistik yang bulat.Pendidikan agama perlu diarahkan untuk mengembangkan iman, akhlak, hati nurani, budi pekerti serta aspek kecerdasan dan keterampilan sehingga terwujud keseimbangan. Dengan demikian, pendidikan agama secara langsung akan mampu memberikan kontribusi terhadap seluruh dimensi perkembangan manusia.

Banyak upaya yang dilakukan oleh pemerintah dalam rangka pembentukan karakter pada peserta didik ada yang melalui integrasi mata pelajaran, integrasi muatan lokal maupun integrasi kegiatan pengembangan diri siswa, dalam hal ini 
kegiatan kesiswaan.MTs .Misbahul Hasan Andungsari Tiris Probolinggo Jember pun sebagai lembaga pendidikan punya andil yang besar dalam pembentukan karakter peserta didik ini tercermin dalam beberapa kegiatan di madrasah ini. pendidikan karakter melalui kegiatan kesiswaan di sekolah ini sudah berjalan dengan baik, ada yang sifatnya Kegiatan rutin Misalnya kegiatan upacara hari Senin, piket kelas, shalat dhuha dan dhuhur berjamaah, setiap pagi ada guru menyambut siswa di pintu gerbang, membaca surat-surat pendek setiap pagi,berdo'a sebelum pelajaran dimulai dan diakhiri, dan mengucapkan salam apabila bertemu guru dan teman. Kegiatan spontan misalnya, mengumpulkan sumbangan ketika ada teman yang terkena musibah atau sumbangan untuk masyarakat ketika terjadi bencana. Keteladanan Misalnya nilai disiplin kehadiran guru yang lebih awal dibanding peserta didik, guru harus memberikan contoh tentang pentingnya kebersihan, kerapihan, sopan santun, perhatian, jujur, dan kerja keras dan percaya diri. Pengkondisian misalnya kelas harus selalu dijaga kebersihannya dengan ada petugas piket kelas, toilet yang bersih, tempat sampah dan lain-lain.

Temuan diatas sesuai dengan teori berikut ;Pengembangan budaya sekolah dan pusat kegiatan belajar dilakukan melalui kegiatan pengembangan diri, yaitu: ${ }^{26}$ Kegiatan rutin ; Kegiatan rutin yaitu kegiatan yang dilakukan peserta didik secara terus menerus dan konsisten setiap saat. Misalnya kegiatan upacara hari Senin, upacara besar kenegaraan, pemeriksaan kebersihan badan, piket kelas, shalat berjamaah, berbaris ketika masuk kelas, berdo'a sebelum pelajaran dimulai dan diakhiri, dan mengucapkan salam apabila bertemu guru, tenaga pendidik, dan teman. Kegiatan spontan ;Kegiatan yang dilakukan peserta didik secara spontan pada saat itu juga, misalnya, mengumpulkan sumbangan ketika ada teman yang terkena musibah atau sumbangan untuk masyarakat ketika terjadi bencana. Keteladanan; Merupakan perilaku, sikap guru, tenaga kependidikan dan peserta didik dalam memberikan contoh melalui tindakan-tindakan yang baik sehingga diharapkan menjadi panutan bagi peserta didik lain. Misalnya nilai disiplin ( kehadiran guru yang lebih awal dibanding peserta didik), kebersihan, kerapihan, kasih sayang, kesopanan, perhatian, jujur, dan kerja keras dan percaya diri. Pengkondisian ;Pengkondisian yaitu penciptaan kondisi yang mendukung keterlaksanaan pendidikan karakter, misalnya kebersihan badan dan pakaian, toilet yang bersih, tempat sampah, halaman yang hijau dengan pepohonan, poster kata-kata bijak di sekolah dan di dalam kelas. Kegiatan ko-kurikuler dan atau kegiatan ekstrakurikuler ; Terlaksananya kegiatan ko-kurikuler dan ekstrakurikuler yang mendukung pendidikan karakter memerlukan perangkat pedoman

${ }^{26}$ Kemendiknas, Panduan Pelaksanaan Pendidikan Karakter, Pusat Kurikulum dan Perbukuan, 2011, 14-18. 
pelaksanaan, pengembangan kapasitas sumber daya manusia, dan revitalisasi kegiatan yang sudah dilakukan sekolah.

Banyak upaya yang dilakukan oleh pemerintah dalam rangka pembentukan karakter pada peserta didik ada yang melalui integrasi mata pelajaran, integrasi muatan lokal maupun integrasi kegiatan pengembangan diri siswa, dalam hal ini kegiatan kesiswaan. Dari hasil temuan menunjukkan bahwa MTs .Misbahul Hasan Andungsari Tiris Probolinggo pun sebagai lembaga pendidikan punya andil yang besar dalam pembentukan karakter peserta didik ini tercermin dalam beberapa kegiatan kesiswaan yang ada yang masing-masing kegiatan mempunyai jadwal pelaksanaan, penanggung jawab/Pembina.Lembaga Madarasah Tsanawiyah Misbahul Hasan Andungsari Tiris Probolinggo dari hasil wawancara dan observasi ada beberapa kegiatan yang ditetapkan antara lain : kegiatan keagamaan dalam rangka pembinaan keimanan dan ketakwaan terhadap Tuhan Yang Maha Esa, MOS, OSIS, penegakkan Tatakrama dan tata tertib sekolah, kepramukaan, upacara Bendera, pembinaan bakat dan minat (olahraga dan seni).

\section{Evaluasi Pendidikan Karakter Melalui Kegiatan Kesiswaan Di Madrasah Tsanawiyah Misbahul Hasan Andungsari Tiris Probolinggo}

1. Proses evaluasi pendidikan karakter melalui kegiatan kesiswaan di MTs .Misbahul Hasan Andungsari Tiris Probolinggo.

Madrasah Tsanawiyah Misbahul Hasan Andungsari Tiris Probolinggo dalam melakukan evaluasi pelaksanaan pendidikan karakter melalui kegiatan kesiswaan dengan beberapa cara yaitu :melakukan pengamatan dan pembinaan langsung dari kepala sekolah kepada bawahan, evaluasi sesame guru/guru sebagai evaluator, melalui perubahan sikap/rekam jejak, dan melalui keterlaksanaan program. 1) Melakukan pengamatan dan pembinaan secara langsung. terlaksananya program pendidikan karakter disekolah/madrasah, kepala sekolah terjun langsung untuk melihat kegiatan-kegiatan yang telah dilaksanakan mulai awal sampai akhir kegiatan, meskipun itu tidak dilakukan setiap ada latihan kegiatan, sehingga kalau dalam pengamatan ada hal-hal yang kurang relevan dengan program yang direncanakan kepala sekolah punya dasar untuk memberikan peringatan atau pembinaan pada orang-orang yang bertanggung jawab dalam hal ini. Dalam hal ini pembinaan yang dilakukan kepala sekolah yaitu secara langsung dan tidak langsung, secara langsung dengan memanggil yang bersangkutan sebagai pelaksana dan penanggung jawab kegiatan untuk diberikan arahan supaya tidak melakukan hal yang sama dengan memberikan masukan atau teguran dengan pendekatan kekeluargaan untuk tetap menjaga hubungan antara pimpinan dengan bawahan agar tetap harmonis, biasanya mengenai ketidak sesuaian rencana 
kegiatan dengan pelaksanaan misalnya, Pembina terlambat datang waktu ada kegiatan atau pulang lebih awal sebelum waktu yang telah ditentukan habis dan lain-lain. Secara tidak langsung misalkan melalui surat peringatan tertulis, melalui rapat dan lain-lain.Pengawasan yang baik adalah pengawasan yang telah built in ketika penyusunan sebuah program. Dalam penyusunan sebuah program, harus sudah ada unsur kontrol di dalamnya.Tujuannya adalah agar seseorang yang melakukan sebuah pekerjaan merasa bahwa pekerjaannya itu diperhatikan oleh atasan, bukan pekerjaan yang tidak diacuhkan atau yang dianggap enteng. Oleh karena itu pengawasan yang terbaik adalah pengawasan yang terbangun dari dalam diri sendiri dan dari system pengawasan yang baik. ${ }^{27}$ Observasi dapat digunakan sebagai salah satu model/strategi penilaian pendidikan karakter, melalui pengumpulan data yang pengisiannya berdasarkan pengamatan langsung terhadap sikap dan perilaku peserta didik dengan cara pembiasaan, keteladanan dan pembentukan karakter peserta didik. Dalam penilaian pendidikan karakter, teknik observasi ini bisa dijadikan model penilaian pendidikan karakter. 2) Selain evaluasi melalui pengamatan langsung yang dilakkan kepala sekolah juga evaluasi bersama-sama antar guru .Pembina kegiatan saling mengingatkan, kepemimpinan di madrasah ini adalah kepemimpinan kolektif, artinya semua guru adalah pemimpin dan wajib saling mengevaluasi terlebih evaluasi diri.Guru sebagai evaluator yaitu melakukan penilaian dan supervise untuk keberlangsungan pendidikan karakter, perlu dilakukan penilaian keberhasilan dengan menggunakan indikator-indikator berupa perilaku semua warga dan kondisi sekolah/instansi. Penilaian ini dilakukan secara terus menerus oleh semua guru melalui berbagai strategi. ${ }^{28}$ Guru sebagai evaluator, guru juga harus selalu mengevaluasi metode pendidikan/pembelajaran yang selama ini dipakai dalam pendidikan karakter. Selain itu juga guru juga harus mampu mengevaluasi sikap perilaku yang ditampilkan dan agenda yang direncanakan. 3) Untuk melihat mutu pendidikan karakter atau tingkat keberhasilan implementasi program pendidikan karakter di sekolah ini dengan cara melihat dari perubahan sikap warga sekolah, misalkan tingkat kedisiplinannya bagaimana, apakah ada perubahan catatan terlambat datang sekolah dari bulan ke bulan, apakah ada perubahan tingkat kebersihan sekolah apa tetap saja, atau ada peningkatan atau malah mundur/turun.Evaluasi lainnya dilakukan dengan melihat pada tingkat

27 Didin Hafifuddin, Manajemen Syariah dalam Praktik, (Jakarta: Gema Insani Perss, 2008), 158.

${ }^{28}$ Novan Ardy Wiyani, Manajemen Pendidikan Karakter, (Yogyakarta : PT Pustaka Insan Madani, 2012),90. 
pelanggaran tata tertib sekolah. Yang terekam dalam catatan buku point siswa.Perubahan sikap atau kumpulan rekaman/catatan tentang peristiwaperistiwa penting yan menonjol dan menarik perhatian dengan karakter peserta didik dalam situasi tertentu.Dari hasil rekaman tersebut dapat ditarik suatu kesimpilan mengenai kreatifitas peserta didik, baik yang bersifat positif maupun negatif, kemudian ditafsirkan dan dimaknai oleh guru sebagai bahan membuat penilaian akhir. Rekam jejak dapat dimanfaatkan oleh guru untuk memperoleh pemahaman yang lebih tepat tentang peserta didik, memperoleh pemahaman tentang sebab-sebab perilaku peserta didik, mengembangkan cara-cara untuk menyesuaikan diri dengan kebutuhan dan kesulitan yang dihadapi peserta didik dalam kegiatan di sekolah.Anecdot record/rekam jejak peserta didik hendaknya dibuat dengan memperhatikan objektif, dalam arti menilai apa adanya, yaitu dengan dibuat catatan oleh guru yang melakukan penyusunan, pencatatan dilakukan segera setelah peristiwa terjadi/berlangsung. ${ }^{29}$ 4) Keterlaksanaan program. Mengevaluasiseberapa persen program yang dilaksanakan itu sesuai dengan rencana apakah banyak yang tidak terlaksana atau terlaksana semua, dari situ sekolah ini mengukur tingkat ketercapaian program atau mutu pendidikan karakter disekolah ini.Temuan tersebut tidak seluruhnya sesuai dengan teori yang ada, namun secara essensi MTs . Misbahul Hasan Andungsari Tiris Probolinggo sudah menerapkan, tetapi tidak dituangkan dalam bentuk evaluasi konkrit berupa instrumen yang terandalkan dan petugas evaluasi yang kompeten; sehingga hasil evaluasi dapat dipertanggungjawabkan dan berguna untuk pengambilan keputusan. Sehingga evaluasi terkesan hanya sebatas wacana saja. Sebagaimna telah dipaparkan oleh beberapa pakar yang mengatakan bahwa: Evaluasi perlu dilakukan untuk mengukur kadar efektivitas dan efisiensi setiap program pendidikan karakter melalui ekstrakurikuler. Pada gilirannya, hasil evaluasi dapat dijadikan sebagai dasar pertimbangan lahirnya kebijakan tentang tindak lanjut program.Prinsip evaluasi tersebut mengindikasikan bahwa evaluasi seyogyanya dilakukan terhadap setiap program pembinaan kesiswaan, baik berkenaan dengan aspek persiapan, pelaksanaan, maupun hasil.Setiap aspek program perlu dievaluasi dengan mempergunakan instrumen yang terandalkan dan petugas evaluasi yang kompeten; sehingga hasil evaluasi dapat dipertanggungjawabkan dan berguna untuk pengambilan keputusan. ${ }^{30}$

2. Partisipasi warga sekolah dalam melakukan evaluasi pelaksanaan pendidikan karakter melalui kegiatan kesiswaan.

\footnotetext{
${ }^{29}$ Mulyasa, manajemen....208.

${ }^{30}$ Kemendikbud, Buku Panduan... 2010, hal. 93.
} 
Dalam melakukan evaluasi MTs .Misbahul Hasan Andungsari Tiris Probolinggo melibatkan semua warga sekolah yaitu kepala madrasah sebagai top leader para pembantu kepala madrasah, Pembina kegiatan, wali kelas, guru dan pihak-pihak yang terkait lainnya. Dengan system kepemimpinan kolektif yang diterapkan oleh MTs .Misbahul Hasan Andungsari Tiris Probolinggo, sehingga semua warga sekolah mempunyai tanggung jawab untuk mensukseskan program pendidikan karakter di madrasah ini sekaligus berhak memberikan penilaian atau evaluasi kepada atasan, teman sejawat maupun bawahan. Hal ini kurang sesuai dengan teori berikut:

Setiap aspek program perlu dievaluasi dengan mempergunakan instrumen yang terandalkan dan petugas evaluasi yang kompeten; sehingga hasil evaluasi dapat dipertanggungjawabkan dan berguna untuk pengambilan keputusan. ${ }^{31}$

\section{Follow Up atau Tindak Lanjut}

Langkah selanjutnya yang di tempuh sekolah ini setelah melakukan evaluasi adalah melakukan follow up atau tindak lanjut, maksudnya sudah ada gambaran untuk melangkah ke depan apa yang akan dilakukan, mempertahankan, merubah, menambah atau mengurangi kegiatan yang di rasa baik atau tidak baik. Dengan cara meneruskan yang sudah ada yang di anggap baik, dan menghilangkan yang di anggap tidak baik untuk dilanjutkan dengan pertimbangan-petimbangan tertentu, atau menambah atau mengganti dengan program/rencana lain yang lebih baik dan sesuai dengan kondisi sekolah, tindak lanjut terkait dengan pelaksana yaitu pembinaan secara terus menerus dengan metode pendekatan kekeluargaan supaya tidak ada yang tersinggung atau tersakiti. Membangun kembali komitmen, menyatukan visi dan misi supaya berjalan seia sekata untuk meminimalisir adanya hambatan atau kendala. Selain itu tindak lanjut terkait dengan masyarakat dalam hal ini orang tua murid MTs .Misbahul Hasan Andungsari Tiris Probolinggo mendatangkan mereka pada momentmoment tertentu misalnya waktu pengambilan raport, rapat wali murid untuk memberikan dukungan sepenuhnya kepada sekolah, karena sebenarnya tanggung jawab pendidikan karakter itu bukan hanya sekolah tapi juga peran orangtua ketika anak-anak di rumah.

\section{Kesimpulan}

A. Perencanaan pelaksanaan pendidikan karakter melalui kegiatan kesiswaan di Madrasah Tsanawiyah Misbahul Hasan Andungsari Tiris Probolinggo relatif

${ }^{31}$ Kemendikbud, Buku Panduan... 2010, hal. 93. 
sesuai dengan perencanaan dalam manajemen. Setidaknya ada tiga unsur perencanaan telah terpenuhi yaitu :

B. Memilih sekumpulan kegiatan. Artinya kegiatan kesiswaan itu sangat banyak dan hampir tak terbatas akan tetapi Madrasah Tsanawiyah Misbahul Hasan Andungsari Tiris Probolinggo telah menetapkan kegiatan-kegiatan yang cocok dan sesuai dengan kondisi sekolah.

C. Memutuskan apa yang dilakukan selanjutnya. Artinya perencanaan yang satu dilaksanakan sambil merencanakan tahap selanjutnya.

D. Kapan, bagaimana, dan oleh siapa. Waktu pelaksanaan sudah ditetapkan, orang-orang yang terlibat langsung juga jelas, dengan demikian perencanaan hanya tinggal menjalankan.

E. Pelaksanaan pendidikan karakter melalui kegiatan kesiswaan di Madrasah Tsanawiyah Misbahul Hasan Andungsari Tiris Probolinggo sudah dilakukan sesuai ketentuan yang berlaku, kepala madrasah yang memiliki model kepemimpinan secara hirarki kebutuhan telah dapat menggerakkan seluruh komponen madrasah untuk secara sadar dan bertanggung jawab bersamasama melakukan tugasnya untuk keberhasilan pendidikan secara menyeluruh.

\section{DAFTAR PUSTAKA}

Abdullah, Yatimin. 2007. Studi Akhlak dalam Perspektif Al Qur'an. Jakarta: Amzah.

Al Munawar, Said Agil Husin. 2002. Al Qur'an:Membangun Tradisi Kesalihan Hakiki Jakarta: Ciputat Press.

Arikunto, Suharsimi . 2005. Prosedur Penelitian. Jakarta: PT. Rineka Cipta.

Arikunto, Suharsimi. 2000. Manajemen Penelitian. Jakarta: Rineka Cipta.

Aqib, Zainal. dan Sujak. 2011. Panduan dan Aplikasi Pendidikan Karakter. Bandung: Yrama Widya.

Azwar, Saifuddin, 1998. Metode Penelitian Kualitatif, Yogyakarta : Pustaka Pelajar

Barnawi dan M. arifin. 2012. Strategi dan kebijakan Pembelajaran Pendidikan Karakter Yogyakarta: Ar Ruzz media.

Departemen agama Rebuplik Indonesia,1989, Al quran dan Terjemah, Semarang: Toha Putra. 
E. Mulyasa. 2004. Manajemen Berbasis Sekolah: Konsep, Strategi, dan Implementasi, Bandung: Rosdakarya.

Estenberg, Kristin G. 2002. Qualitative methods in Social Research.New York: Mc Graw hill, 2002).

Faisal, Sanapiah. 2005. Format-Format Penelitian Sosial, Dasar-dasar dan Aplikasi. Jakarta: Raja Grafindo.

Guba, Egon G. \& Yvonna S. Lincoln. 1981. Effective Evaluation. San Fransisco; Jossey-Bass Publishers.

Hafifuddin,Didin. 2008.Manajemen Syariah dalam Praktik, Jakarta: Gema Insani Perss.

Handoko,T. Hani, 2000.Manajemen, Yogyakarta: BPFE-Yogyakarta.

Hidayat ,Komaruddin. $2010 . \quad$ "Kultur Sekolah”. http://www.uinjkt.ac.id/index.php/ category table/1456-membangun-kultursekolah-.html.

Ihsan, Fuad .2001. Dasar-dasar Pendidikan: Komponen MKDK. Jakarta: Pt. Renika Cipta.

Iskandar. 2009. Metodologi Penelitian Pendidikan dan Sosial (Kuantitatif dan Kualitatif), Jakarta: Gunung PersadaPress.

Iskandar. 2009. Metodologi Penelitian Kualitatif, Aplikasi untuk Penelitian Pendidikan, Hukum, Ekonomi Manajemen, Sosial, humaniora, Politik, Agama, dan Filsafat, (Jakarta : GP. Press.

Janah, Fathul .2009. Manajemen Akademik Lembaga Pendidikan Tinggi Islam. (Yogyakarta : Safiria Insania Press.

Kemendikbud .2010. Buku Panduan Pendidikan Karakter di Sekolah Menengah Pertama. 